\title{
Extraction of oleuropein from olive leaves and applicability in foods
}

\author{
Carolina Fernanda Sengling Cebin Coppa, Bruna Leonel Gonçalves, Sarah Hwa. In Lee, Valéria Martinelli Ramos \\ Nunes, Cintia Bernando Gonçalves, Christianne Elizabete Costa Rodrigues, Carlos Augusto Fernandes Oliveira* \\ Department of Food Engineering, School of Animal Science and Food Engineering, University of São Paulo, Pirassununga, \\ SP, Brazil
}

*Corresponding Author: Carlos Augusto Fernandes Oliveira, Departent of Food Engineering, School of Animal Science and Food Engineering, University of São Paulo, Pirassununga, SP, Brazil. Tel: +55 19 $3565-4173$; Fax: +55 19 3565-4284. Email: carlosaf@usp.br

Received: 26 June 2020; Accepted: 20 September 2020; Published: 31 October 2020

(c) 2020 Codon Publications

OPEN ACCESS (c) (i) (을

REVIEW ARTICLE

\begin{abstract}
Oleuropein is a phenolic compound found in all parts of the olive tree (Olea europaea L.), although at higher levels in the leaves. The health benefits associated with the consumption of oleuropein include the prevention of cardiac diseases, improvement in lipid metabolism, and decrease in obesity-related disturbs, among others. In addition, several studies have shown that oleuropein presents antimicrobial, antioxidant, and inflammatory properties. The scientific interest in the methods for the extraction of oleuropein from olive leaves has markedly increased in recent years, aiming to extend its application in foods, cosmetics, and drugs. In this review, the extraction procedures available in the literature are described according to their advantages and disadvantages that directly affect the extraction yield. The applicability of oleuropein in food products is also discussed.
\end{abstract}

Keywords: antioxidants; extraction techniques; food applications; phenolic compounds; oleuropein

\section{Introduction}

Oleuropein (Figure 1) is a phenolic compound mostly found in olive (Olea europaea L.) leaves (Aouidi et al., 2012), being classified as the ester formed by 3,4-dihydroxyphenyl ethanol (hydroxytyrosol) and the glucoside of elenolic acid (Tan et al., 2003). The compound was firstly detected in olives in 1908 and described by Bourquelot and Vintilesco as a green thin solid with a melting point of $89^{\circ} \mathrm{C}$ (Leonardis et al., 2008). Oleuropein is almost absent in olive oil due to its high solubility in water and enzymatic degradation during oil extraction (Paiva-Martins and Pinto, 2008). Olive leaves may contain $60-90 \mathrm{mg} / \mathrm{g}$ of oleuropein in dry mass (Ansari et al., 2011). However, the oleuropein content depends on several factors, including olive variety, plant region, season, olive maturation during harvesting, and the type of olive processing (Al-Rimawi et al., 2014; Hassen et al., 2015). During the maturation of olives, oleuropein is biotransformed through hydrolysis into hydroxytyrosol, also known as 3,4-dihydroxyphenyl ethanol, which is also reported as a potential antioxidant agent found in olive oil (Leonardis et al., 2008). In this process, the ester bond linking hydroxytyrosol to the glucoside of elenolic acid is hydrolyzed, and hydroxytyrosol is released along with the elenolic acid glucoside (Hassen et al., 2015). Natively, hydroxytyrosol is rarely available freely, except for olives in the advanced maturation stage, due to the oleuropein hydrolysis. The faster the olive maturation, the higher is its content in hydroxytyrosol (Artajo et al., 2007).

Extracts from leaves rich in biophenols have protective effects in foods with a high content of unsaturated fat, also providing health benefits to the consumers (Jimenez et al., 2011; Nunes et al., 2016). Several studies have revealed that oleuropein is effective against bacterial cells (Dominciano et al., 2016; Tripoli et al., 2005), virus (Micol et al., 2005), and inflammatory processes (Visioli et al., 2002), among others. Moreover, oleuropein can avoid cardiac diseases, improve lipid metabolism, minimize 


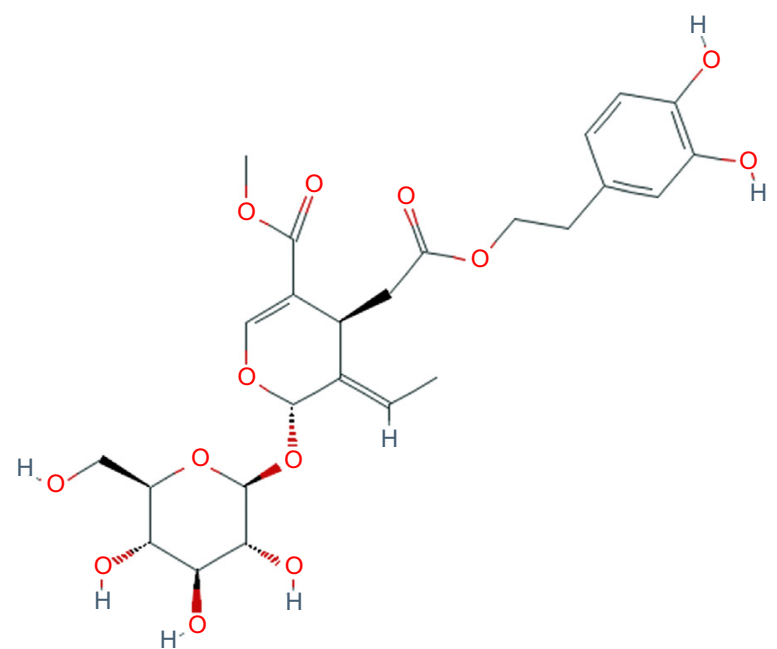

Figure 1. Chemical structure of oleuropein (National Center for Biotechnology Information 2020).

troubles related to obesity, and protect enzymes and cells from oxidizing reactions (Japón-Luján and Luque De Castro, 2007). It was demonstrated that oleuropein and other compounds found in the olive leaves acted as antioxidant agents, preventing the formation of free radicals (Al-Rimawi et al., 2017a, 2017b) due to their efficacy in chelating metals, such as copper and iron, and catalyzing reactions of free radical production such as lipid oxidation (Mokhtar et al., 2014). The antioxidant activity is credited for the presence of the $o$-diphenolic group in the oleuropein molecule (Hayes et al., 2011). Oleuropein and its derivative hydroxytyrosol have demonstrated synergistic effects with vitamin $C$ and tocopherol (vitamin E) (Japón-Luján and Luque De Castro, 2007). In corroboration with potential food applications, the human absorption of oleuropein-aglycone, hydroxytyrosol, and tyrosol is up to $60 \%$ (Vissers et al., 2002), being rapidly distributed among several organs and tissues, including the heart, brain, and liver (Bazoti et al., 2010). These properties have stimulated the development of suitable and efficient methods to extract oleuropein from olive leaves, each one having advantages and disadvantages that directly affect the extraction yield. Sampling, solvent composition, time, and extraction temperature are the main parameters affecting the efficiency of the extraction methods for oleuropein (Mustafa and Turner, 2011; Xynos et al., 2012). The aim of this review was to describe and critically evaluate the oleuropein extraction procedures available in the literature and discuss the applicability of this compound in food products.

\section{Methods for Extraction of Oleuropein from Olive Leaves}

An overview of the most applied procedures for the extraction of oleuropein from olive leaves is illustrated in Figure 2. The most commonly used techniques involve conventional solid-liquid extraction and ultrasound-assisted extraction. Moreover, emerging technologies including microwave-assisted, supercritical fluid, pressurized liquid and membrane separation techniques have attracted considerable research interest regarding their potential use for oleuropein extraction.

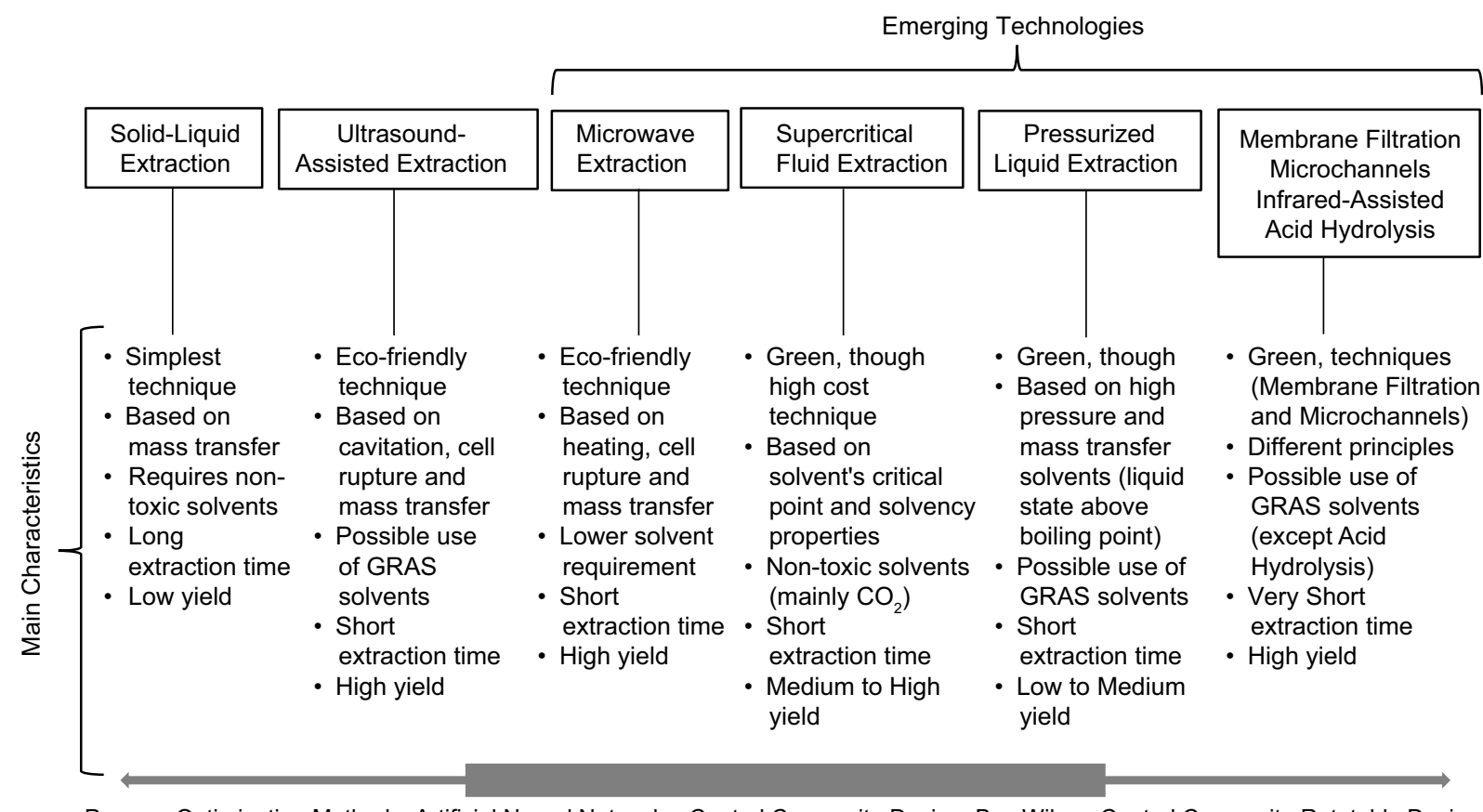

Process Optimization Methods: Artificial Neural Networks, Central Composite Design, Box Wilson-Central Composite Rotatable Design

Figure 2. The main characteristics of the methods used for extraction of oleuropein from olive leaves. 


\section{Solid-liquid extraction}

Solid-liquid extraction is considered as one of the simplest techniques for the isolation of bioactive compounds, based on the mass transfer between the solvent and the solid sample during a suitable extraction time, with or without mixing or heating (Coppa et al., 2017; Japón-Luján and Luque De Castro, 2006). This method is widely employed for the extraction of oleuropein, although it requires a high-quality solvent and a long extraction period when compared to other methods (Prado et al., 2013). Moreover, it is crucial to extract oleuropein from olive leaves using nontoxic solvents, since this phenolic compound is mainly used in food products for human consumption (Coppa et al., 2017). Table 1 presents the main outcomes from the studies available in the literature on the solid-liquid extraction methods for oleuropein and their respective yields. The Soxhlet technique and the cold solvent method are the most commonly used solid-liquid procedures for oleuropein extraction (Otero et al., 2020). Sahin et al. (2011) carried out the extraction of phenolic compounds from vegetable sources with the Soxhlet method using methanol (100\%) and supercritical fluid, with the former technique providing better yields $(37.8 \mathrm{mg} / \mathrm{g}$ of oleuropein). However, a mixture of ethanol, isopropanol, and water $(50: 25: 25)$ provided a lower yield $(18.5 \mathrm{mg} / \mathrm{g})$ of oleuropein (Uzel, 2018). Recently, Lama-Muñoz et al. $(2019,2020)$ extracted oleuropein using the Soxhlet procedure from olive leaves employing a mixture of ethanol and water (60:40), reaching 65.6 to $122.3 \mathrm{mg} / \mathrm{g}$ of oleuropein.

The cold solvent extraction, also known as maceration, is frequently applied for the extraction of bioactive compounds from solid vegetable matrices (Rahmanian et al., 2015). However, the main drawbacks involved in the oleuropein extraction by maceration are the requirement of long extraction time and the low yield (Ávila et al., 2007; Maran et al., 2013). Ansari et al. (2011) extracted oleuropein from olive leaves by maceration at $60^{\circ} \mathrm{C}$ with different solvents and extraction times. Deionized water as the solvent and $4 \mathrm{~h}$ of extraction time resulted in the best yield $(13 \mathrm{mg} / \mathrm{g})$ as longer times caused oleuropein oxidation. Benincasa et al. (2019) used distilled water and obtained a slightly higher yield $(19.3 \mathrm{mg} / \mathrm{g})$ of oleuropein, when compared with the values reported by Ansari et al. (2011). A different approach was studied by Jimenez et al. (2011), who scalded the olive leaves at $95^{\circ} \mathrm{C}$ for $4.5 \mathrm{~min}$, followed by cooling with cold water before drying at $45^{\circ} \mathrm{C}$ for $18 \mathrm{~h}$. About $760 \mathrm{~g}$ of dried leaves were grounded and macerated in ethanol: water solution $(1: 1 \mathrm{v} / \mathrm{v})$ for 24 $\mathrm{h}$ at room temperature. Under these conditions, a high concentration $(290 \mathrm{mg} / \mathrm{kg})$ of oleuropein was obtained in the final extracts. Coppa et al. (2017) macerated olive leaves with ethanol and water $(70: 30)$ at $25^{\circ} \mathrm{C}$ for $120 \mathrm{~min}$, obtaining a yield of $180 \mathrm{mg} / \mathrm{g}$ in the freeze-dried extract. Compared with the previously mentioned finding, Deng et al. (2017) observed a lower yield $(5.2 \mathrm{mg} / \mathrm{g}$ ) using methanol and water $(80: 20)$ at $50^{\circ} \mathrm{C}$ during a longer extraction time (282 $\mathrm{min})$.

Stamatopoulos et al. (2012) also extracted oleuropein using ethanol and water solution (7:3 v: v) under agitation for $5 \mathrm{~min}$. However, the authors performed a steam bleaching as a pretreatment to facilitate extraction of the phenolic compounds from olive leaves. As a result, the oleuropein content in the extracts and its antioxidant

Table 1. Experimental conditions and yields of solid-liquid extraction of oleuropein from olive leaves.

\begin{tabular}{|c|c|c|c|c|c|}
\hline \multirow{2}{*}{$\begin{array}{l}\text { Solid-liquid extraction } \\
\text { method }\end{array}$} & \multicolumn{3}{|c|}{ Experimental conditions } & \multirow{2}{*}{ Yield (mg/g) } & \multirow{2}{*}{ Reference } \\
\hline & Temperature $\left({ }^{\circ} \mathrm{C}\right)$ & Solvent (proportion) & Time (minutes) & & \\
\hline Soxhlet extraction & 50 & Methanol (100\%) & $\mathrm{NR}$ & 37.8 & Sahin et al. (2011) \\
\hline Soxhlet extraction & 160 & $\begin{array}{l}\text { Ethanol: isopropanol: } \\
\text { water }(50: 25: 25)\end{array}$ & 120 & 18.5 & Uzel (2018) \\
\hline Soxhlet extraction & NR & Ethanol: water (60:40) & 240 & 65.6 & Lama-Muñoz et al. (2019) \\
\hline Soxhlet extraction & NR & Ethanol: water (60:40) & 240 & 122.3 & Lama-Muñoz et al. (2020) \\
\hline Maceration & 60 & Deionized water (100\%) & 4 & 13 & Ansari et al. (2011) \\
\hline Maceration & RT & Ethanol: water (50:50) & 1440 & 290.0 & Jimenez et al. (2011) \\
\hline Maceration ${ }^{1}$ & 40 & Ethanol: water (70:30) & 60 & 9.2 & Stamatopoulos et al. (2012) \\
\hline Maceration ${ }^{1,2}$ & $40-85$ & Ethanol: water $(70: 30)$ & 30 & 103.1 & Stamatopoulos et al. (2013) \\
\hline Maceration & 25 & Ethanol: water (70:30) & 120 & $180.0^{3}$ & Coppa et al. (2017) \\
\hline Maceration & 50 & Methanol: water $(80: 20)$ & 282 & 5.2 & Deng et al. (2017) \\
\hline Maceration & 60 & Distilled water (100\%) & NR & 19.3 & Benincasa et al. (2019) \\
\hline
\end{tabular}


potential were 35 and 13 times superior, respectively, when compared to extracts without the pretreatment. Although this procedure provides shorter extraction times and simpler techniques, the authors pointed out that pretreatment for over 10 min can degrade the oleuropein. Subsequently, Stamatopoulos et al. (2013) isolated oleuropein from olive leaves by multiple extraction stages optimized by a whitening technique, in which leaves were submitted to three extraction stages performed with 60 min duration time per stage, using different ethanol solutions $(20,40,55,70,80$, and $90 \%, \mathrm{v} / \mathrm{v})$ and temperatures of $40,60,65,70$, and $85^{\circ} \mathrm{C}$. At each stage, samples were collected every $10 \mathrm{~min}$, filtered, and characterized in terms of phenolic composition by the Folin-Ciocalteau assay. The best conditions were $30 \mathrm{~min}$ of extraction at $85^{\circ} \mathrm{C}$ using solvent ethanol $70 \%$, reaching an oleuropein yield of 23 times higher (103.1 mg of oleuropein/g of dried mass) than the value (4.6 $\mathrm{mg}$ of oleuropein/g of dried mass) obtained in the conventional method $\left(48 \mathrm{~h}\right.$ at $\left.40^{\circ} \mathrm{C}\right)$. However, according to the authors, it is economically preferable to conduct the extraction at $40^{\circ} \mathrm{C}$ since the yield was only $17 \%$ greater than when using a temperature of $85^{\circ} \mathrm{C}$.

\section{Ultrasound-assisted extraction}

In the food industry, ultrasound is a technique widely used for the extraction of vitamins A, D, and E; antioxidant compounds; flavonoids; phenols; polysaccharides; alkaloids; and natural compounds used as additives in several food products (Yang and Zhang, 2008). The extraction process using ultrasound equipment is a simple procedure that consists in placing the solid of interest in contact with the solvent in a glass-made vessel inside the apparatus, allowing easy handling and control of the time and temperature desired (García-Salas et al., 2010; Klejdus et al., 2009). The equipment produces the cavitation phenomenon, which will cause mechanical stress on cells, a consequent of increase of their dilatation, leading to cell rupture and hydration of the material, and facilitating the mass transfer between the solid material and the extractor solvent (Esclapez et al., 2011). It is also possible to substitute the organic solvent for generally recognized as safe (GRAS) products to improve the extraction (Vilkhu et al., 2008). According to Shirsath et al. (2012), the device frequency is a crucial parameter for the extraction, as low frequencies of about $20 \mathrm{kHz}$ are more effective on plant materials, as olive leaves. Due to the effects promoted by cavitation, the bubbles can implode more easily than those generated at high frequency, thus facilitating the release of the substances of interest (Esclapez et al., 2011). The ultrasound-assisted extraction of oleuropein has been performed either using ultrasonic bath or homogenizer (probe) devices, as presented in Table 2. By using methanol as the extraction solvent, Jerman et al. (2010) obtained $12.3 \mathrm{mg} / \mathrm{g}$ of oleuropein in a ultrasound bath for $20 \mathrm{~min}$. Achat et al. (2012) obtained a much higher yield of oleuropein $(414.3 \mathrm{mg} / \mathrm{g})$ after maceration of olive in ultrasound bath at $16^{\circ} \mathrm{C}$ for $45 \mathrm{~min}$, which is comparable to solid-liquid extraction yields. The highest yield (812.9 mg/g) was described by Yasemi et al. (2017), who extracted oleuropein in methanol: water (80:20) using an ultrasound bath of $25 \mathrm{kHz}$. In contrast, lower yields of 134.5 and $7.0 \mathrm{mg} / \mathrm{g}$ using ultrasound bath were reported by Ismaili et al. (2016) and Deng et al. (2017), respectively. Other applications of ultrasound bath extraction methods yielded $27.3 \mathrm{mg} / \mathrm{g}$ (Cifà et al., 2018) and 106.5 $\mathrm{mg} / \mathrm{g}$ (Irakli et al., 2018).

Table 2. Experimental conditions and yields of ultrasound-assisted extraction of oleuropein from olive leaves.

\begin{tabular}{|c|c|c|c|c|c|}
\hline \multirow{2}{*}{$\begin{array}{l}\text { Device } \\
\text { (frequency, kHz) }\end{array}$} & \multicolumn{3}{|c|}{ Experimental conditions } & \multirow{2}{*}{$\begin{array}{l}\text { Yield } \\
(\mathrm{mg} / \mathrm{g})\end{array}$} & \multirow{2}{*}{ Reference } \\
\hline & Temperature $\left({ }^{\circ} \mathrm{C}\right)$ & Solvent (proportion) & Time (minutes) & & \\
\hline UB (30) & 44 & Methanol $(100 \%)$ & 20 & 12.2 & Jerman et al. (2010) \\
\hline UB (25) & 16 & Olive oil (10\%) & 45 & 414.3 & Achat et al. (2012) \\
\hline UB (NR) & NR & Acetonitrile: tetrahydrofuran $(50: 50)$ & 30 & 134.5 & Ismaili et al. (2016) \\
\hline UB (NR) & 47 & Methanol: water $(80: 20)$ & 30 & 7.0 & Deng et al. (2017) \\
\hline UB (80) & 25 & Methanol: water (80:20) & 10 & 812.9 & Yasemi et al. (2017) \\
\hline UB (35) & 25 & Ethanol: water $(70: 30)$ & 120 & 27.3 & Cifà et al. (2018) \\
\hline UB (37) & 60 & Acetone: water $(50: 50)$ & 10 & 106.5 & Irakli et al. (2018) \\
\hline UH (20) & 50 & Ethanol: water $(75: 25)$ & 3 & 76.7 & Xie et al. (2015) \\
\hline UH (20) & 60 & Ethanol: water $(80: 20)$ & 5 & 11.4 & Giacometti et al. (2018) \\
\hline UH (40) & 20 & Ethanol: water (60:40) & 17.91 & 69.9 & Lama-Muñoz et al. (2019) \\
\hline
\end{tabular}

UB: ultrasonic bath; UH: ultrasonic homogenizer (probe); NR: not reported. 
Regarding the extraction using ultrasonic homogenizers, a yield of $76.7 \mathrm{mg} / \mathrm{g}$ was obtained by Xie et al. (2015) using ethanol and water $(75: 25)$ in a very short time (3 min). Other solvent combinations in ultrasoundassisted extractions with probes included ethanol and water at 80:20 (Giacometti et al., 2018) and 60:40 (LamaMuñoz et al., 2019), although their respective yields (11.4 and 69.9) were lower than those previously mentioned.

\section{Extraction by emerging technologies}

In recent years, other nonconventional technologies have been proposed for the extraction of oleuropein, including microfluid systems (microchannels) and infrared-assisted methods (Table 3). In particular, microchannels have gained extensive attention because of higher yields of oleuropein achieved, low operational costs, and low environmental impact of the procedure (Yasemi et al., 2017). In addition, intense research activities are currently being addressed to include special statistical approaches for the optimization of the extraction of oleuropein, such as Artificial Neural Networks (Yasemi, 2020), Central Composite Design (CCD) (Lamprou et al., 2020), and Box Wilson-Central Composite Rotatable Design (Vural et al., 2020).

\section{Microwave-assisted extraction}

Similar to ultrasound, microwave-assisted techniques are also widely applied for the extraction of bioactive compounds from vegetal matrices.

Microwave extraction can be assumed to be an ecofriendly technique due to the low solvent requirement. This extraction can provide a good yield, since the heating caused by the waves leads to distension of the plant cells, causing the rupture of the structures where the compounds of interest are concentrated (Alupului et al., 2012). Moreover, this method requires a reduced extraction time when compared to other techniques (Ghassempour et al., 2008). According to Pérez-Serradilla and Luque de Castro (2011), the microwave extraction improves the extraction efficiency of phenolic compounds in a shorter time concerning conventional techniques that demand about $24 \mathrm{~h}$ of extraction. Rafiee et al. (2011) tested the extraction of phenolic compounds from olive leaves using a microwave device and different solvents, in which ethanol provided the best results with an extraction yield of $88.3 \mathrm{mg} / \mathrm{g}$ after $15 \mathrm{~min}$ of microwave exposure. Sahin et al. (2017) used response surface methodology (RSM) and artificial neural networks to optimize the yield extraction of oleuropein from olive leaves by

Table 3. Experimental conditions and yields of emerging technologies for the extraction of oleuropein from olive leaves.

\begin{tabular}{|c|c|c|c|c|c|}
\hline \multirow{2}{*}{ Type of technology } & \multicolumn{3}{|c|}{ Experimental conditions } & \multirow{2}{*}{$\begin{array}{l}\text { Yield } \\
(\mathrm{mg} / \mathrm{g})\end{array}$} & \multirow{2}{*}{ Reference } \\
\hline & Temperature $\left({ }^{\circ} \mathrm{C}\right)$ & Solvent (proportion) & Time (minutes) & & \\
\hline MAE (NR) & NR & Ethanol (100\%) & 15 & 88.3 & Rafiee et al. (2011) \\
\hline MAE (250-300 W) & NR & Water (100\%) & 2 & 60 & Sahin et al. (2017) \\
\hline SFE (300 bars) & NR & $\mathrm{CO}_{2}$ (with $20 \%$ ethanol) & 10 & 51 & Xynos et al. (2012) \\
\hline SFE (150 bars) & 35 & $\mathrm{CO}_{2}(100 \%)$ & NR & 360 & Baldino et al. (2018) \\
\hline PLE (300 bars) & $\begin{array}{l}115 \\
150\end{array}$ & $\begin{array}{l}\text { Ethanol }(100 \%) \\
\text { Water }(100 \%)\end{array}$ & $\begin{array}{l}5 \\
5\end{array}$ & $\begin{array}{l}43 \\
34\end{array}$ & Xynos et al. (2012) \\
\hline PLE (103 bars) & 120 & Ethanol: water (50:50) & 20 & NR & Lozano-Sánchez et al. (2014) \\
\hline PLE (103 bars) & 60 & Ethanol $(100 \%)$ & NR & 73.6 & Rosa et al. (2019) \\
\hline MF (5000 Da) & $N R$ & None & NR & $2.6^{1}$ & Khemakhem et al. (2017) \\
\hline MF (300 Da) & NR & None & NR & $26.2^{1}$ & Khemakhem et al. (2017) \\
\hline IAE & 90 & Ethanol: water (55.35:44.65) & 221 & 14.0 & Abi-Khattar et al. (2019) \\
\hline $\begin{array}{l}\text { Microchannels (inner diameter: } \\
800 \mu \mathrm{m} \text {; length: } 8.5 \mathrm{~mm} \text { ) }\end{array}$ & RT & Deionized water $(100 \%)$ & $<1$ & $68.7^{2}$ & Naleini et al. (2015) \\
\hline $\begin{array}{l}\text { Microchannels (inner diameter: } \\
600 \mu \mathrm{m} \text {; length: } 70 \mathrm{~mm} \text { ) }\end{array}$ & 35 & Ethyl acetate (100\%) & 0.5 & $96.3^{2}$ & Yasemi et al. (2017) \\
\hline $\begin{array}{l}\text { Microchannels (inner diameter: } \\
800 \mu \mathrm{m} \text {; length: } 8.5 \mathrm{~mm} \text { ) }\end{array}$ & 40 & Deionized water (100\%) & $<1$ & $70.9^{2}$ & Heydarid et al. (2018) \\
\hline Acid hydrolysis & 40 & $2 \% \mathrm{H}_{2} \mathrm{SO}_{4}$ & NR & 43.1 & Lamprou et al. (2020) \\
\hline
\end{tabular}


microwave-assisted extraction. The RSM design and the artificial neural networks model were found to be suitable for predicting the oleuropein amounts and the increment/decrement tendency of the extraction responses, with a maximum yield value of $60 \mathrm{mg} / \mathrm{g}$ of oleuropein. In particular, artificial neural networks models have been frequently used to optimize and control the oleuropein extraction process, aiming to save energy and time, also providing a more favorable product (Yasemi, 2020).

\section{Supercritical fluid extraction}

The extraction using supercritical fluid offers a great advantage related to the use of organic solvents, since it is possible to reduce their quantity, besides occurring low degradation of the target compounds (Reverchon and De Marco, 2006). In this method, the supercritical fluid is used as the solvent, since its solubility is similar to the liquid diffusivity and the gas (mainly carbon dioxide $\left[\mathrm{CO}_{2}\right]$ ), thus allowing the dilution of a great variety of natural compounds (Zhang et al., 2018). In addition, it has solvency properties that change radically close to its critical points due to changes in temperature and pressure (Zhang et al., 2018). Supercritical fluid extraction is also considered a green technique due to the use of nontoxic solvents (El and Karakaya, 2009). Furthermore, if nonpolar compounds are used, it is possible to reduce energy expenditure on extraction (Khosravi-Darani and Mozafari, 2009). The most commonly used solvent for the extraction of oleuropein in supercritical media is $\mathrm{CO}_{2}$, which is inert, nonflammable, and environmentally friendly (Ignat et al., 2011). Xynos et al. (2012) evaluated the extraction of oleuropein from olive leaves by supercritical fluid, testing nontoxic solvents such as $\mathrm{CO}_{2}$, water, and ethanol (Table 3). The authors were able to extract $30 \%$ of oleuropein in the dry extract (equivalent to the recovery of $51 \mathrm{mg}$ of oleuropein per gram of olive leaves), with $20 \%$ ethanol as co-solvent and supercritical $\mathrm{CO}_{2}$ at 300 bars. However, Baldino et al. (2018) obtained higher yields using supercritical $\mathrm{CO}_{2}$ at 150 bars and $35^{\circ} \mathrm{C}$, with a maximum yield of $360 \mathrm{mg} / \mathrm{g}$ of oleuropein. A possible disadvantage of the extraction methods based on supercritical $\mathrm{CO}_{2}$ is the requirement of high pressures, which increases the cost of the equipment and, consequently, the final product (Herrero et al., 2006).

\section{Pressurized liquid extraction}

Extraction with pressurized liquid is also known as accelerated solvent extraction, enhanced solvent extraction, fluid extraction, or high-pressure solvent extraction (Zhang et al., 2018). This technique applies high pressures during the extraction process, which preserves the solvents in the liquid state above their boiling point, resulting in high solubility and diffusion rates, and the introduction of the solvent into the matrix. In this method, the extraction time is reduced, and the solvent exhibits better behavior compared to the other techniques (Zhang et al., 2018). Pressurized liquid can be heated to elevated temperatures and pressures, allowing the solvent to remain in its liquid state even at higher temperatures (above boiling temperature). When water and ethanol are subjected to 200 bar pressure and up to $200^{\circ} \mathrm{C}$, the liquids remain liquid, even under conditions above the atmospheric and boiling limits (Coppa et al., 2017). When this technique is used to extract compounds from plant sources, it is possible to facilitate the solubility of the components of interest with the solid matrix, by accelerating the release kinetics of the bioactive compounds from the solid plant material. The extraction of oleuropein through pressurized liquid technique has been used with "green" solvents, such as ethanol and water under pressures not exceeding 200 bar and temperatures varying from $25^{\circ} \mathrm{C}$ to $200^{\circ} \mathrm{C}$, as presented in Table 3.

Xynos et al. (2012) compared the results obtained by the extraction of oleuropein from olive leaves through pressurized liquid using ethanol or water as solvents. Maximum yields of 43 and $34 \mathrm{mg} / \mathrm{g}$ were obtained using ethanol at $115^{\circ} \mathrm{C}$ and water at $150^{\circ} \mathrm{C}$, respectively. It can be observed from these results that, using the pressurized liquid technique, a higher oleuropein yield was obtained due to the high pressures applied in this type of extraction. In spite of the great yields obtained using this method, the high temperatures applied can originate several undesirable compounds due to reactions in the matrix, which may also be extracted along with oleuropein (Herrero et al., 2013). Lozano-Sánchez et al. (2014) carried out a study to recover bioactive compounds from olive leaves by pressurized liquid extraction at 103 bars using different combinations of ethanol and water at temperatures ranging from 40 to $175^{\circ} \mathrm{C}$. The best solvent proportion and temperature were ethanol: water (50:50) and $120^{\circ} \mathrm{C}$, respectively. Although the authors reported that the main compounds found in the extracts were oleuropein and hydroxytyrosol, no quantification or extraction yields for oleuropein were provided. Rosa et al. (2019) also used pressurized liquid extraction with ethanol $(100 \%)$ at 103 bars and $60^{\circ} \mathrm{C}$ and observed a yield of $73.6 \mathrm{mg} / \mathrm{g}$ of oleuropein.

\section{Extraction with other emerging techniques}

Among new extraction technologies, methods based on separation by membranes have been recently proposed for oleuropein and other bioactive compounds available in aqueous solutions (Otero et al., 2020). In membrane separation, the selective permeation of dissolved molecules is achieved through a semipermeable polymer or inorganic support, thus providing high concentration and purity of the compound (Yasemi et al., 2017). In addition, the process requires low energy consumption, since it is operated at low temperatures (Otero et al., 2020). Khemakhem et al. (2017) extracted oleuropein 
by ultrafiltration (pore size of membrane: $5000 \mathrm{Da}$ ) and nanofiltration (pore size of membrane: $300 \mathrm{Da}$ ) processes, obtaining 10 times higher levels of oleuropein in the retentate from nanofiltration than from the nanofiltration process (yields of 2.6 and $26.2 \mathrm{mg} / \mathrm{g}$, respectively).

An infrared-assisted extraction was proposed by AbiKhattar et al. (2019) using ethanol: water (55.35:44.65) at $90^{\circ} \mathrm{C}$ for $221 \mathrm{~min}$. The process was previously optimized by RSM in order to increase the recoveries of oleuropein and other polyphenols from olive leaves, yielding 14.0 $\mathrm{mg} / \mathrm{g}$ of oleuropein. Microchannel devices have also been used for the extraction of oleuropein, since these systems are based on the principle that lower molecular distance leads to greater diffusion, increasing the possibility of mass transfer (Otero et al., 2020). Naleini et al. (2015) developed a microfluid device to extract oleuropein from ethyl acetate into aqueous phase, obtaining a yield of $68.7 \%$. The authors stated that microchannel methods are efficient and more economical and environmentally friendly than conventional techniques applied for oleuropein extraction. In another study conducted by Yasemi et al. (2017), microchannels provided a higher yield of oleuropein (96.3\%) after optimization of the operating parameters by RSM, when compared with Soxhlet, maceration, and ultrasound-assisted techniques. RSM optimization of microchannel extraction of oleuropein was also performed by Heydarid et al. (2018), who obtained a maximum extraction yield of $70.9 \%$ under the following conditions: deionized water as extractant phase, temperature of $40{ }^{\circ} \mathrm{C}$, flow rate ratio of 0.16 , and residence time of $0.1010 \mathrm{~min}$. The extraction yield of $70.93 \%$ was obtained under the above conditions with relative standard deviation of $2.0 \%$.

A new method for extracting phenolic compounds from olive leaves based on acid hydrolysis by sulfuric acid was proposed by Lamprou et al. (2020). The authors optimized the experimental conditions according to a CCD comprising the most important factors that affect the extraction process, and the resulting yield of oleuropein was $43.1 \mathrm{mg} / \mathrm{g}$.

\section{Application of Oleuropein in Foods}

The beneficial effects of oleuropein have attracted considerable research interest in recent years, aiming at its application as a natural product in many industrial areas, especially in foods (Erbay and Icier, 2010). The majority of studies on the potential food applications evaluated the incorporation of olive leaves' extracts containing known levels of oleuropein and its derivatives, as presented in Table 4. However, there is limited information on the use of purified oleuropein in food formulations. An important application of oleuropein-containing extracts is the improvement of the nutritional value of foods by increasing their polyphenol content. In this context, Chiou et al. (2007) enriched the palm tree, olive tree, and sunflower oils with olive leaf extracts containing 120 and $240 \mathrm{mg}$ of total polyphenols $/ \mathrm{kg}$ of oil, and observed high transference rates from the supplemented oils to potato chips during the frying process. This result was in agreement with the findings from Erbay and Icier (2010), who observed that polyphenols did not degrade significantly after absorption by fried foods. In fact, the frying process of potatoes in olive, sunflower, and soya oils enriched with $100 \mathrm{mg}$ of total phenolic compounds $/ \mathrm{kg}$ of oil retained $3-12 \%$ of oleuropein (Nunes et al., 2016). Furthermore, the consumption of approximately $200 \mathrm{~g}$ of these chips provided nearly $6 \mathrm{mg}$ of oleuropein. However, it has been demonstrated that, throughout the frying process, a reduction in the oleuropein contents may occur, both in the oil and in the potatoes (Chiou et al., 2013; Nunes et al., 2016; Rahmanian et al., 2015). Ahmad-Qasem et al. (2014) also used olive leaves' extract rich in oleuropein at $19,280 \mathrm{mg} / \mathrm{kg}$ to improve the nutritional value of dehydrated apple cubes, concluding that the final products presented higher oleuropein contents (about $1.928 \mathrm{mg} /$ $100 \mathrm{~g}$ dry weight), when compared with controls.

Oleuropein as a natural antioxidant can be a potential replacement for synthetic food antioxidants, such as butylhydroxyanisole (BHA) and butylhydroxytoluene (BHT), considering that their promotion effects on carcinogenesis have been speculated (Farag et al., 2007). According to Erbay and Icier (2010), the combined antioxidant activities of oleuropein and its derivative hydroxytyrosol are higher than BHA or BHT. Jimenez et al. (2011) reported the oxidative stability of sunflower, canola, and soybean oils supplemented with three types of olive leaf extracts: hydroalcoholic extract, pressed juice, and extracts obtained by supercritical $\mathrm{CO}_{2}$. Each extract contained polyphenols at concentrations of 250 and $630 \mathrm{mg} / \mathrm{kg}$ of oil. For the extracts containing $250 \mathrm{mg} / \mathrm{kg}$ of oil, the induction times of the sunflower oil containing hydroalcoholic extracts, extract obtained from $\mathrm{CO}_{2}$ supercritical, and pressurized juice were 21.1, 26.3, and $2.7 \mathrm{~h}$, respectively. For canola oil containing the same order of extracts, the results were 9.5, 12.6, and $1.8 \mathrm{~h}$, respectively. For soybean oil, induction times of 6.7, 6.9, and $1.7 \mathrm{~h}$ were found in the same order as the extracts described above. For the polyphenol concentration of $630 \mathrm{mg} / \mathrm{kg}$ oil, sunflower oil with hydroalcoholic extract, supercritical $\mathrm{CO}_{2}$, and pressurized juice resulted in induction times of 30.7, 35.1, and $3.0 \mathrm{~h}$, respectively. For the canola oil, the induction times were 11.0, 13.4, and $2.0 \mathrm{~h}$, while for the soybean oil, the times were 7.6, 8.4, and $1.4 \mathrm{~h}$ for the same extract order as mentioned, respectively. These data are consistent with those reported previously by Salta et al. (2007), who evaluated the stability of vegetable oils enriched with olive leaves' 
Table 4. The main applications of olive leaves' extracts containing known levels of oleuropein as a food additive.

\begin{tabular}{|c|c|c|c|}
\hline Type of food & $\begin{array}{l}\text { Oleuropein } \\
\text { concentration } \\
\text { (mg/L or } \mathrm{kg})\end{array}$ & Main outcomes & Reference \\
\hline $\begin{array}{l}\text { Palm oil, olive oil, and } \\
\text { sunflower oil }\end{array}$ & $120-240$ & $\begin{array}{l}\text { High transference rates of oleuropein from the supplemented } \\
\text { oils to the enriched potato chips during the frying process }\end{array}$ & Chiou et al. (2007) \\
\hline $\begin{array}{l}\text { Olive oil, palm oil, } \\
\text { sunflower oil, and vegetable } \\
\text { shortening }\end{array}$ & 200 & $\begin{array}{l}\text { Antioxidant and oxidative capacities increased in types of oils, } \\
\text { especially in the olive oil }\end{array}$ & Salta et al. (2007) \\
\hline $\begin{array}{l}\text { Sunflower, canola, and } \\
\text { soybean oil }\end{array}$ & 250 and 630 & $\begin{array}{l}\text { Oxidative stability (expressed as induction times) increased in all } \\
\text { types of oils, with maximum values }(6.7-35.1 \mathrm{~h} \text { ) at } 630 \mathrm{mg} / \mathrm{L}\end{array}$ & $\begin{array}{l}\text { Jimenez et al. } \\
\text { (2011) }\end{array}$ \\
\hline Dried apple & 19,280 & $\begin{array}{l}\text { Incorporation of oleuropein improved the nutritional value of } \\
\text { dried apples, reaching } 1928 \mathrm{mg} / 100 \mathrm{~g} \text { dry weight }\end{array}$ & $\begin{array}{l}\text { Ahmad-Qasem } \\
\text { et al. (2014) }\end{array}$ \\
\hline Cow's milk and yogurt & 100 and 200 & $\begin{array}{l}\text { Oleuropein improved the functionality of milk and yogurt, without } \\
\text { any effect on their sensory attributes }\end{array}$ & $\begin{array}{l}\text { Zoidou et al. } \\
\text { (2014) }\end{array}$ \\
\hline $\begin{array}{l}\text { Tabaq-Maz (fried mutton } \\
\text { ribs) }\end{array}$ & 3000,6000 and 9000 & $\begin{array}{l}\text { Increase of lipid oxidative stability and storage quality, and } \\
\text { reduction of mesophilic and psychrophilic counts, as well as } \\
\text { mold and yeast counts by all oleuropein levels tested }\end{array}$ & Dua et al. (2015) \\
\hline $\begin{array}{l}\text { Extra-virgin and refined } \\
\text { olive oil }\end{array}$ & 30 and 60 & $\begin{array}{l}\text { Oxidative stability (expressed as induction times) increased in } \\
\text { extra-virgin and refined oils at } 30 \text { and } 60 \mathrm{mg} / \mathrm{L}\end{array}$ & Coppa et al. (2017) \\
\hline Frozen hamburger & 2500,5000 , and 7500 & Effective antioxidant activity at oleuropein levels $\geq 5000 \mathrm{mg} / \mathrm{kg}$ & $\begin{array}{l}\text { Al-Rimawi et al. } \\
\text { (2017a) }\end{array}$ \\
\hline $\begin{array}{l}\text { Fresh hamburger stored } \\
\text { at } 4^{\circ} \mathrm{C}\end{array}$ & 500,1000 , and 1500 & $\begin{array}{l}\text { Effective antioxidant activity and prolonged shelf life of } \\
\text { hamburgersat } 1500 \mathrm{mg} / \mathrm{kg}\end{array}$ & $\begin{array}{l}\text { Al-Rimawi et al. } \\
\text { (2017b) }\end{array}$ \\
\hline Pasteurized milk & 3600 & $\begin{array}{l}\text { Oleuropein reduced mesophilic bacteria to an undetectable level } \\
\text { after } 6 \text { days }\end{array}$ & $\begin{array}{l}\text { Palmeri et al. } \\
\text { (2019) }\end{array}$ \\
\hline Halal minced beef & 854 and 4272 & $\begin{array}{l}\text { Effective antioxidant activity at } 4272 \mathrm{mg} / \mathrm{kg} \text {, along with reduction } \\
\text { of nearly } 1.5 \text { and } 3 \text { log cycles of pathogens (Salmonella } \\
\text { enterica ser. Enteritidis, and Escherichia coli } 0157: \mathrm{H} 7 \text { ) and } \\
\text { psychrotrophic counts, respectively }\end{array}$ & $\begin{array}{l}\text { Djenane et al. } \\
\text { (2019) }\end{array}$ \\
\hline Vegetable pâté & 500 and 1000 & $\begin{array}{l}\text { Reduction of } 0.5-1.0 \mathrm{log} \text { cycles of mesophilic bacteria, lactic } \\
\text { acid bacteria, Streptococci, Enterococci, molds and yeasts, } \\
\text { especially at } 1000 \mathrm{mg} / \mathrm{kg}\end{array}$ & $\begin{array}{l}\text { Difonzo et al. } \\
\text { (2019) }\end{array}$ \\
\hline
\end{tabular}

extracts, which contained about $185 \mathrm{mg}$ oleuropein $/ \mathrm{kg}$ of oil. Before the addition of the extracts in olive and palm oil, the samples had induction times of 13.3 and $24 \mathrm{~h}$, respectively. After the enrichment of the oils, their stability increased to 20.8 and $43.1 \mathrm{~h}$, respectively, confirming that the addition of extracts of olive leaves in vegetable oils contribute to the increase of their oxidative stability. Coppa et al. (2017) added lyophilized extracts rich in oleuropein in extra-virgin and refined olive oils, to verify the performance of the compound as a natural antioxidant. The results showed that the supplemented extra virgin and refined olive oils had $2-\mathrm{h}$ and 1 -h increases in their induction times, respectively, thereby confirming that the addition of oleuropein-containing extract increases the oxidative stability of olive oil.

The inclusion of 500 and $1000 \mathrm{mg} / \mathrm{kg}$ of oleuropein in vegetable pâtés reduced $0.5-1.0$ log cycles of mesophilic bacteria, lactic acid bacteria, Streptococci, Enterococci, molds, and yeasts in the product, in a dose-response relationship (Difonzo et al., 2019). Oleuropein is also applicable as a natural preservative for pasteurized milk, since its fortification at $3600 \mathrm{mg} / \mathrm{L}$ reduced total mesophilic bacteria to an undetectable level after 6 days and increased its shelf life by 60\% (Palmeri et al., 2019). Regarding meat products, Al-Rimawi et al. (2017a) evaluated the replacement of sodium erythorbate, a chemical antioxidant used in the meat industry, with oleuropein-rich olive leaves' extracts as a natural antioxidant in frozen hamburgers stored at $-12^{\circ} \mathrm{C}$. The samples were treated with different concentrations of oleuropein (2500, 5000, and $7500 \mathrm{mg} / \mathrm{kg}$ ), and the storage period was from 1 to 6 months. The concentration of $5000 \mathrm{mg} /$ $\mathrm{kg}$ oleuropein presented the best antioxidant effect in the experimental hamburgers, which could be used as an alternative natural additive in this food. A similar delay in the oxidation process was observed in fresh hamburgers added with olive leaf extract containing oleuropein at $5000 \mathrm{mg} / \mathrm{kg}$ and stored at $4^{\circ} \mathrm{C}$ (Al-Rimawi et al., 2017b). Dua et al. (2015) found that oleuropein increased the lipid oxidative stability and the storage quality of fried mutton ribs (Tabaq-Maz), and significantly reduced the mesophilic and psychrophilic counts, as well as the mold and yeast counts. In a recent study, Djenane et al. (2019) 
observed that oleuropein at $4272 \mathrm{mg} / \mathrm{kg}$ in Halal minced beef reduced nearly 1.5 and $3 \log$ cycles of pathogens (Salmonella enterica ser. Enteritidis and Escherichia coli O157:H7) and psychrotrophic counts, respectively.

Nunes et al. (2016) studied the effect of olive leaf extracts containing about $21 \%$ oleuropein and $\alpha$-tocopherol on biodegradable films. A small interaction was observed between the polymer matrix and the antioxidants evaluated, besides the migration of the antioxidants to the food. This fact suggests that the material is only suitable for foods with a shorter shelf life (Marcos et al., 2014). Encapsulating bioactive compounds can help improve their properties, such as controlling the release of chemical constituents (Chatzidaki et al., 2016). As an example, Mohammadi et al. (2016) stated that the encapsulation of bioactive compounds could reduce the unpleasant flavors of oils enriched with olive leaf extracts. In addition, they may help to preserve bioactive compounds from high temperatures employed in the frying process. Several studies have demonstrated that encapsulation increases the stability of oleuropein and hydroxytyrosol in water/oil emulsions, thereby indicating that the technique may help to improve the organoleptic properties of foods added with oleuropein, also protecting bioactive compounds from degradation in the small intestine (Chatzidaki et al., 2016; Markopoulos et al., 2009; Souilem et al., 2014).

In addition to the bitter taste of oleuropein, which may potentially limit its inclusion in food preparations (Ozturk, 2014), the stability of this compound in food processing also deserves attention for deeper studies (Erbay and Icier, 2010). Zoidou et al. (2014) conducted the first study on the application of oleuropein in milk and yoghurt, aiming to improve their functional attributes. The authors found that oleuropein remained stable during milk heating and coagulation, and was not hydrolyzed by acid production neither metabolized by lactic acid bacteria nor inhibit its growth. Oleuropein was soluble at concentrations of $0.1 \mathrm{mg} / \mathrm{mL}$ or $0.2 \mathrm{mg} / \mathrm{mL}$ without adding any particular taste to the products. According to the authors, from a technological point of view, the presence of oleuropein did not interfere with the milk and yoghurt process, and considering the biological value of the compound, it can be added as an active ingredient in these products for the production of new functional foods with health benefits.

\section{Concluding Remarks}

Oleuropein and the related phenolic compounds present in olive leaves' extracts have antioxidant, antimicrobial, and anti-inflammatory activities, among other health benefit effects. Therefore, its potential application in many types of industries has been explored. The most applied procedures for the extraction of oleuropein from olive leaves include solid-liquid, ultrasound-assisted, microwave, supercritical fluid, and pressurized liquid techniques. These procedures have several practical advantages and satisfactory oleuropein yields, although ultrasoundassisted and microwave methods are considered as low cost and environment-friendly techniques due to the use of nontoxic solvents. In recent years, statistical optimization approaches and new emerging technologies have been proposed for the extraction of oleuropein, with microchannels gaining increased research interest because of the higher yields of oleuropein provided, low operational costs, and low environmental impact of the procedure.

The main application of oleuropein extracts in food products is intended to replace synthetic antioxidants and also act as a natural preservative due its antimicrobial activity. As indicated by the outcomes of several studies available in the literature, the use of small quantities of oleuropein can improve the shelf life of products with high fat contents, including margarine, butter, meat, and edible oils, thereby avoiding lipidic oxidation and providing health benefits to the consumers. However, studies addressing food applications using purified oleuropein are strongly needed. The bitterness and the low stability of oleuropein are important limitations for the general use of olive leaves' extracts or pure oleuropein in food preparations. Encapsulation techniques have demonstrated promising results to improve the sensorial properties of supplemented foods and to protect the bioactive compounds in the food matrix. Further studies are needed to evaluate the stability of encapsulated oleuropein in complex food matrices under different storage conditions.

\section{Acknowledgements}

This study was financed in part by the Coordenação de Aperfeiçoamento de Pessoal de Nível Superior-Brasil (CAPES)_Finance Code 001. The authors would like to thank FAPESP and CNPq (308615/2016-6) for financial support.

\section{Conflict of Interest Disclosure}

The authors declare that there are no conflicts of interest relevant to this study.

\section{References}

Abi-Khattar, A.M., Rajha, H.N., Abdel-Massih, R.M., Maroun, R.G., Louka, N. and Debs, E., 2019. Intensification of polyphenol extraction from olive leaves using ired-irrad ${ }^{\circ}$, an environmentallyfriendly innovative technology. Antioxidants 8: 227. https:// doi.org/10.3390/antiox8070227 
Achat, S., Tomao, V., Madani, K., Chibane, M., Elmaataoui, M., Dangles, O. and Chemat, F., 2012. Direct enrichment of olive oil in oleuropein by ultrasound-assisted maceration at laboratory and pilot plant scale. Ultrasonics Sonochemistry 19: 777-786. https://doi.org/10.1016/j.ultsonch.2011.12.006

Ahmad-Qasem, M.H, Santacatalina, J.V., Barrajón-Catalán, E., Carreres, J.E., Micol, V. and García-Pérez, J.V., 2014. Influence of drying on the retention of olive leaf polyphenols infused into dried apple. Food and Bioprocess Technology 8: 120-133. https://doi.org/10.1007/s11947-014-1387-6

Al-Rimawi, F., Odeh, I., Bisher, A., Abbadi, J. and Qabbajeh, M., 2014. Effect of geographical region and harvesting date on antioxidant activity, phenolic and flavonoid content of olive leaves. Journal of Food Nutrition Research 2: 925-930. https://doi. org/10.12691/jfnr-2-12-11

Al-Rimawi, F., Tarawa, M., and Elama, C., 2017a. Oleuropein from olive leaf extract as natural antioxidant of frozen hamburger. American Journal of Food Science and Technology 7: 406-412. https://doi.org/10.17265/2159-5828/2017.08.005

Al-Rimawi, F., Tarawa, M.S. and Elama, C., 2017b. Olive leaf extract as natural antioxidant additive of fresh hamburger stored at $4{ }^{\circ} \mathrm{C}$. American Journal of Food Science and Technology 5: 162-166. https://doi.org/10.12691/ajfst-5-4-7

Alupului, A., Călinescu, I. and Lavric, V., 2012. Microwave extraction of active principles from medicinal plants. UPB Scientific Bulletin Serie B 74: 129-142. Available at: https:// www.scientificbulletin.upb.ro/rev_docs_arhiva/fullf4b_141413. pdf.

Ansari, M., Kazemipour, M. and Fathi, S., 2011. Development of a simple green extraction procedure and HPLC method for determination of oleuropein in olive leaf extract applied to a multisource comparative study. Journal of the Iranian Chemistry Society 8: 38-47. https://doi.org/10.1007/BF03246200

Aouidi, F., Dupuy, N., Artaud, J., Roussos, S., Msallem, M., Gaime, P.I. and Hamdi, M., 2012. Rapid quantitative determination of oleuropein in olive leaves (Olea europaea) using mid-infrared spectroscopy combined with chemometric analyses. Industial Crops and Products 37: 292-297. https://doi. org/10.1016/j.indcrop.2011.12.024

Artajo, L.S., Romero, M.P., Suárez, M. and Motilva, M.J., 2007. Partition of phenolic compounds during the virgin olive oil industrial extraction process. European Food Research and Technology 225: 617-625. https://doi.org/10.1007/ s00217-006-0456-0

Ávila, N.S., Priego Capote, F. and Luque de Castro, M.D., 2007. Ultrasound-assisted extraction and silylation prior to gas chromatography-mass spectrometry for the characterization of the triterpenic fraction in olive leaves. Journal of Chromatography A 1165: 158-165. https://doi.org/10.1177/1082013208089563

Baldino, L., Della Porta, G., Osseo, L.S., Reverchon, E. and Adami, R., 2018. Concentrated oleuropein powder from olive leaves using alcoholic extraction and supercritical $\mathrm{CO}_{2}$ assisted extraction. Journal of Supercritic Fluids 133: 65-69. https://doi. org/10.1016/j.supflu.2017.09.026

Bazoti, F.N., Gikas, E. and Tsarbopoulos, A., 2010. Simultaneous quantification of oleuropein and its metabolites in rat plasma by liquid chromatography electrospray ionization tandem mass spectrometry. Biomedical Chromatography 24: 506-515. https://doi.org/10.1002/bmc.1319

Benincasa, C., Santoro, I., Nardi, M., Cassano, A. and Sindona, G., 2019. Eco-friendly extraction and characterisation of nutraceuticals from olive leaves. Molecules 24: 3481. https://doi. org/10.3390/molecules24:193481

Chatzidaki, M.D., Arik, N., Monteil, J., Papadimitriou, V., Leal-Calderon, F. and Xenakis, A., 2016. Microemulsion versus emulsion as effective carrier of hydroxytyrosol. Colloids and Surfaces B Biointerfaces 137: 146-151. https://doi.org/10.1016/j.colsurfb.2015.04.053

Chiou, A., Kalogeropoulos, N., Efstathiou, P., Papoutsi, M. and Andrikopoulos, N.K., 2013. French fries oleuropein content during the successive deep frying in oils enriched with an olive leaf extract. International Journal of Food Science and Technology 48: 1165-1171. https://doi.org/10.1111/ijfs.12070

Chiou, A., Salta, F.N., Kalogeropoulos, N., Mylona, A., Ntalla, I. and Andrikopoulos, N.K., 2007. Retention and distribution of polyphenols after pan-frying of French fries in oils enriched with olive leaf extract. Journal of Food Science 72: S574-S584. https://doi.org/10.1111/j.1750-3841.2007.00493.x

Cifá, D., Skrt, M., Pittia, P., Di Mattia, C. and Ulrih, N.P., 2018. Enhanced yield of oleuropein from olive leaves using ultrasound-assisted extraction. Food Science and Nutrtion 6: 11281137. https://doi.org/10.1002/fsn3.654

Coppa, C.F.S.C., Rosim, R.E., Oliveira, C.A.F., Rodrigues, C.E.C. and Gonçalves, C.B., 2017. Extraction of oleuropein from olive leaves using a hydroalcoholic solvent. Brazilian Journal of Food Technology 20: e2016169. https://doi. org/10.1590/1981-6723.16916

Deng, J., Xu, Z., Xiang, C., Liu, J., Zhou, L., Li, T., Yang, Z. and Ding, C., 2017. Comparative evaluation of maceration and ultrasonic-assisted extraction of phenolic compounds from fresh olives. Ultrasonics Sonochemistry 37: 328-334. https://doi. org/10.1016/j.ultsonch.2017.01.023

Difonzo, G., Squeo, G., Calasso, M., Pasqualone, A. and Caponio, F., 2019. Physico-chemical, microbiological and sensory evaluation of ready-to-use vegetable pâté added with olive leaf extract. Foods 8: 138. https://doi.org/10.3390/foods8040138

Djenane, D., Gómez, D., Yangüela, J., Roncales, P. and Ariño, A., 2019. Olive leaves extract from Algerian oleaster (Olea europaea var. sylvestris) on microbiological safety and shelf-life stability of raw Halal minced beef during display. Foods 8: 10. https://doi. org/10.3390/foods 8010010

Dominciano, L.C.C., Lee, S.H.I., Corassin, C.H., De Martinis, E.C.P. and Oliveira, C.A.F., 2016. Effects of oleuropein and peracetic acid as sanitizing agents for inactivation of biofilms. The Open Conference Proceedings Journal 7: 1-6. https://doi. org/10.2174/2210289201607010001

Dua, S., Bhat, F., and Kumar, S., 2015. Effect of oleuropein on the oxidative stability and storage quality of Tabaq-Maz, fried mutton ribs. Food Bioscience 12: 84-92. https://doi.org/10.1016/j. fbio.2015.08.002

El, S.N. and Karakaya, S., 2009. Olive tree (Olea europaea) leaves: potential beneficial effects on human health. Nutrition Reviews 67: 632-638. https://doi.org/10.1111/j.1753-4887.2009.00248.x 
Erbay, Z. and Icier, F., 2010. The importance and potential uses of olive leaves. Food Reviews Internatioal 26: 319-334. https://doi. org/10.1080/87559129.2010.496021

Esclapez, M.D., García-Pérez, J.V., Mulet, A. and Cárcel, J.A., 2011. Ultrasound-assisted extraction of natural products. Food Engineering Reviews 3: 108-120. https://doi.org/10.1007/ s12393-011-9036-6

Farag, R.S., Mahmoud, E.A. and Basuny, A.M., 2007. Use crude olive leaf juice as a natural antioxidant for the stability of sunflower oil during heating. Institute of Food Science and Technology 42: 107-115. https://doi.org/10.1111/j.1365-2621.2006.01374.x

García-Salas, P., Morales-Soto, A., Segura-Carretero, A. and Fernández-Gutiérrez, A., 2010. Phenolic-compound-extraction systems for fruit and vegetable samples. Molecules 15: 88138826. https://doi.org/10.3390/molecules15128813

Ghassempour, A., Heydari, R., Talebpour, Z., Fakhari, A.R., Rassouli, A., Davies, N. and Aboul-Enein, H.Y., 2008. Study of new extraction methods for separation of anthocyanins from red grape skins: analysis by HPLC and LC-MS/MS. Journal of Liquid Chromatography and Relatated Technologies 31: 26862703. https://doi.org/10.1080/10826070802353247

Giacometti, J., Žauhar, G. and Žuvić, M., 2018. Optimization of ultrasonic-assisted extraction of major phenolic compounds from olive leaves (Olea europaea L.) using response surface methodology. Foods 7: 149. https://doi.org/10.3390/ foods7090149

Hassen, I., Casabianca, H. and Hosni, K., 2015. Biological activities of the natural antioxidant oleuropein: exceeding the expectation-a mini-review. Journal of Functional Foods 18: 926-940. https://doi.org/10.1016/j.jff.2014.09.001

Hayes, J.E., Allen, P., Brunton, N., O'Grady, M.N.O. and Kerry, J.P., 2011. Phenolic composition and in vitro antioxidant capacity of four commercial phytochemical products: olive leaf extract (Olea europaea L.), lutein, sesamol and ellagic acid. Food Chemistry 126: 948-955. https://doi.org/10.1016/j. foodchem.2010.11.092

Herrero, M., Castro-Puyana, M., Mendiola, J.A. and Ibañez, E., 2013. Compressed fluids for the extraction of bioactive compounds. TrAC-Trends in Analytical Chemistry 43: 67-83. https://doi.org/10.1016/j.trac.2012.12.008

Herrero, M., Cifuentes, A. and Ibanez, E., 2006. Sub- and supercritical fluid extraction of functional ingredients from different natural sources: plants, food-by-products, algae and microalgae-a review. Food Chemistry 98: 136-148. https://doi.org/10.1016/j. foodchem.2005.05.058

Heydarid, R., Rahimi, M. and Naleini, N., 2018. Optimization of oleuropein extraction from organic extracts using a microfluidic device and response surface methodology. Herbal Medicines Journal 3: 60-69. Available at: http://eprints.lums. ac.ir/1847/1/3.pdf.

Ignat, I., Volf, I. and Popa, V.I., 2011. A critical review of methods for characterisation of polyphenolic compounds in fruits and vegetables. Food Chemistry 126: 1821-1835. https://doi. org/10.1016/j.foodchem.2010.12.026

Irakli, M., Chatzopoulou, P. and Ekateriniadou, L., 2018 Optimization of ultrasound-assisted extraction of phenolic compounds: oleuropein, phenolic acids, phenolic alcohols and flavonoids from olive leaves and evaluation of its antioxidant activities. Industrial Crops and Production 124: 382-388. https://doi.org/10.1016/j.indcrop.2018.07.070

Ismaili, A., Heydari, R. and Rezaeepour, R., 2016. Monitoring the oleuropein content of olive leaves and fruits using ultrasoundand salt-assisted liquid-liquid extraction optimized by response surface methodology and high-performance liquid chromatography. Journal of Separation Science 39: 405-411. https://doi. org $/ 10.1002 /$ jssc. 201500795

Japón-Luján, R. and Luque de Castro, M.D., 2006. Superheated liquid extraction of oleuropein and related biophenols from olive leaves. Journal of Chromatography A 1136: 185-191. https://doi. org/10.1016/j.chroma.2006.09.081

Japón-Luján, R. and Luque De Castro, M.D., 2007. Small branches of olive tree: a source of biophenols complementary to olive leaves. Journal of Agriculture and Food Chemistry 55: 45844588. https://doi.org/10.1021/jf070215t

Jerman, T., Trebše, P. and Mozetič Vodopivec, B., 2010. Ultrasoundassisted solid liquid extraction (USLE) of olive fruit (Olea europaea) phenolic compounds. Food Chemistry 123: 175-182. https://doi.org/10.1016/j.foodchem.2010.04.006

Jimenez, P., Masson, L., Barriga, A., Chávez, J. and Robert, P., 2011. Oxidative stability of oils containing olive leaf extracts obtained by pressure, supercritical and solvent-extraction. European Journal of Lipid Science and Technology 113: 497-505. https:// doi.org/10.1002/ejlt.201000445

Khemakhem, I., Gargouri, O.D., Dhouib, A., Ayadi, M.A. and Bouaziz, M., 2017. Oleuropein rich extract from olive leaves by combining microfiltration, ultrafiltration and nanofiltration. Separation and Purification Technology 172: 310-317. https:// doi.org/10.1016/j.seppur.2016.08.003

Khosravi-Darani, K. and Mozafari, M.R., 2009. Supercritical fluids technology in bioprocess industries: a review. Journal of Biochemical Technology 2: 144-152.

Klejdus, B., Kopecký, J., Benešová, L. and Vacek, J., 2009. Solidphase/supercritical-fluid extraction for liquid chromatography of phenolic compounds in freshwater microalgae and selected cyanobacterial species. Journal of Chromatography A 1216: 763-771. https://doi.org/10.1016/j.chroma.2008.11.096

Lama-Muñoz, A., del Mar Contreras, M., Espínola, F., Moya, M., Romero, I. and Castro, E., 2019. Optimization of oleuropein and luteolin-7-o-glucoside extraction from olive leaves by ultrasound-assisted technology. Energies 12: 2486. https://doi. org/10.3390/en12132486

Lama-Muñoz, A., del Mar Contreras, M., Espínola, F., Moya, M., Romero, I. and Castro, E., 2020. Content of phenolic compounds and mannitol in olive leaves extracts from six Spanish cultivars: extraction with the Soxhlet method and pressurized liquids. Food Chemistry 320: 126626. https://doi.org/10.1016/j. foodchem.2020.126626

Lamprou, G.K., Vlysidis, A., Tzathas, K. and Vlyssides, A.G., 2020. Statistical optimization and kinetic analysis of the extraction of phenolic compounds from olive leaves. Journal of Chemical Technology and Biotechnology 95: 457-465. https://doi. org/10.1002/jctb.6049 
Leonardis, A., Aretini, A., Alfano, G., Macciola, V. and Giancarlo, R., 2008. Isolation of a hydroxytyrosol-rich extract from olive leaves (Olea europaea L.) and evaluation of its antioxidant properties and bioactivity. European Food Research and Technology 226: 653-659. https://doi.org/10.1007/s00217-007-0574-3

Lozano-Sanchez, J., Castro-Puyana, M., Mendiola, J.A., SeguraCarretero, A., Cifuentes, A. and Obáñez, E., 2014. Recovering bioactive compounds from olive oil filter cake by advanced extraction techniques. International Journal of Molecular Sciences 15: 16270-16283. https://doi.org/10.3390/ ijms150916270

Maran, J.P., Manikandan, S., Vigna Nivetha, C. and Dinesh, R., 2013. Ultrasound assisted extraction of bioactive compounds from Nephelium lappaceum L. fruit peel using central composite face centered response surface design. Arabian Journal of Chemistry 10: S1145-S1157. https://doi.org/10.1016/j.arabjc.2013.02.007

Marcos, B., Sárraga, C., Castellari, M., Kappen, F., Schennink, G. and Arnau, J., 2014. Development of biodegradable films with antioxidant properties based on polyesters containing $\alpha$-tocopherol and olive leaf extract for food packaging applications. Food Packaging and Shelf Life 1: 140-150. https://doi.org/10.1016/j. fpsl.2014.04.002

Markopoulos, C., Vertzoni M., Agalias A., Magiatis, P. and Reppas, C., 2009. Stability of oleuropein in the human proximal gut. Journal of Pharmacy and Pharmacology 61: 143-149. https://doi.org/10.1211/jpp.61.02.0002

Micol, V., Caturla, N., Pérez-Fons, L., Más, V., Pérez, L. and Estepa, A., 2005. The olive leaf extract exhibits antiviral activity against viral haemorrhagic septicaemia rhabdovirus (VHSV). Antiviral Research 66: 129-136. https://doi.org/10.1016/j. antiviral.2005.02.005

Mohammadi, A., Jafari, S.M., Assadpour, E. and Faridi Esfanjani, A., 2016. Nano-encapsulation of olive leaf phenolic compounds through WPC-pectin complexes and evaluating their release rate. International Journal of Biological Macromolecules 82: 816-822. https://doi.org/10.1016/j.ijbiomac.2015.10.025

Mokhtar, S.M., Youssef, K.M. and Morsy, N.E., 2014. The effects of natural antioxidants on colour, lipid stability and sensory evaluation of fresh beef patties stored at $4^{\circ} \mathrm{C}$. Journal of Agroalimentary Processes and Technologies 20: 282-292. Available at: https:// www.journal-of-agroalimentary.ro/admin/articole/9274.1L44 Vol_20(3)_2014_282_292.pdf.

Mustafa, A. and Turner, C., 2011. Pressurized liquid extraction as a green approach in food and herbal plants extraction: a review. Analytica Chimica Acta 703: 8-18. https://doi.org/10.1016/j. aca.2011.07.018

Naleini, N., Rahimi, M. and Heydari, R., 2015. Oleuropein extraction using microfluidic system. Chemical Engineering and Processing: Process Intensification 92: 1-6. https://doi. org/10.1016/j.cep.2015.03.023

National Center for Biotechnology Information, 2020. PubChem compound database, CID: 5281544. Available at: https://pubchem.ncbi.nlm.nih.gov/compound/. Accessed May 2020.

Nunes, M.A., Pimentel, F.B., Costa, A.S.G., Alves, R.C. and Oliveira, M.B.P.P., 2016. Olive by-products for functional and food applications: challenging opportunities to face environmental constraints. Innovative Food Science and Emerging Technologies 35: 139-148. https://doi.org/10.1016/j. ifset.2016.04.016

Otero, D.M., Oliveira, F.M., Lorini, A., Antunes, B.F., Oliveira, R.M. and Zambiazi, R.C., 2020. Oleuropein: methods for extraction, purifying and applying. Revista Ceres 67: 315-329. https://doi. org/10.1590/0034-737x202067040009

Ozturk, A., 2014. Understanding the characteristics of oleuropein for table olive processing. Journal of Food Processing and Technology 5: 1000328. https://doi.org/10.4172/2157-7110.1000328

Paiva-Martins, F. and Pinto, M., 2008. Isolation and characterization of a new hydroxytyrosol derivative from olive (Olea europaea) leaves. Journal of Agriculture and Food Chemistry 56: 55825588. https://doi.org/10.1021/jf800698y

Palmeri, R., Parafati, L., Trippa, D., Siracusa, L., Arena, E., Restuccia, C. and Fallico, B., 2019. Addition of olive leaf extract (OLE) for producing fortified fresh pasteurized milk with an extended shelf life. Antioxidants 8: 255. https://doi.org/10.3390/antiox8080255.

Pérez-Serradilla, J.A. and Luque de Castro, M.D., 2011. Microwaveassisted extraction of phenolic compounds from wine lees and spray-drying of the extract. Food Chemistry 124: 1652-1659. https://doi.org/10.1016/j.foodchem.2010.07.046

Prado, I.M., Prado, G.H.C., Prado, J.M. and Meireles, M.A.A., 2013. Supercritical $\mathrm{CO}_{2}$ and low-pressure solvent extraction of mango (Mangifera indica) leaves: global yield, extraction kinetics, chemical composition and cost of manufacturing. Food and Bioproducts Processing 91: 656-664. https://doi.org/10.1016/j. foodchem.2010.07.046

Rafiee, Z., Jafari, S.M., Alami, M. and Khomeiri, M., 2011. Microwave-assisted extraction of phenolic compounds from olive leaves; a comparison with maceration. Journal of Animal and Plant Science 21: 738-745. Available at: http://www.thejaps. org.pk/docs/21-4/33.pdf

Rahmanian, N., Jafari, S.M. and Wani, T.A., 2015. Bioactive profile, dehydration, extraction and application of the bioactive components of olive leaves. Trends in Food Science and Technology 42: 150-172. https://doi.org/10.1016/j.tifs.2014.12.009

Reverchon, E. and De Marco, I., 2006. Supercritical fluid extraction and fractionation of natural matter. Journal of Supercritical Fluids 38: 146-166. https://doi.org/10.1016/j.supflu.2006.03.020

Rosa, G.S., Vanga, S.K., Gariepy, Y. and Raghavan, V., 2019. Comparison of microwave, ultrasonic and conventional techniques for extraction of bioactive compounds from olive leaves (Olea europaea L.). Innovative Food Science and Emerging Technologies 58: 102234. https://doi.org/10.1016/j. ifset.2019.102234

Sahin, S., Bilgin, M. and Dramur, M.U., 2011. Investigation of oleuropein content in olive leaf extract obtained by supercritical fluid extraction and soxhlet methods. Separation Science and Technology 46: 1829-1837. https://doi.org/10.1080/01496395.2 011.573519

Sahin, S., Samli, R., Tan, A.S.B., Barba, F.J., Chemat, F., Gravotto, G. and Lorenzo, J.M., 2017. Solvent-free microwave-assisted extraction of polyphenols from olive tree leaves: antioxidant and antimicrobial properties. Molecules 22: 1056. https://doi. org/10.3390/molecules22071056 
Salta, F.N., Mylona, A., Chiou, A., Boskou, G. and Andrikopoulos, N.K., 2007. Oxidative stability of edible vegetable oils enriched in polyphenols with olive leaf extract. Food Science and Technology International 13: 413-421. https://doi. org/10.1177/1082013208089563

Shirsath, S.R., Sonawane, S.H. and Gogate, P.R., 2012. Intensification of extraction of natural products using ultrasonic irradiations-a review of current status. Chemical Engeering and Processing: Process Intensification 53: 10-23. https://doi.org/10.1016/j. cep.2012.01.003

Souilem, S., Kobayashi, I., Neves, M.A., Sayadi, S., Ichikawa, S. and Nakajima, M., 2014. Preparation of monodisperse food-grade oleuropein-loaded W/O/W emulsions using microchannel emulsification and evaluation of their storage stability. Food and Bioprocess Technology 7: 2014-2027. https://doi.org/10.1007/ s11947-013-1182-9

Stamatopoulos, K., Chatzilazarou, A. and Katsoyannos, E., 2013. Optimization of multistage extraction of olive leaves for recovery of phenolic compounds at moderated temperatures and short extraction times. Foods 3: 66-81. https://doi.org/10.3390/ foods3010066

Stamatopoulos, K., Katsoyannos, E., Chatzilazarou, A. and Konteles, S.J., 2012. Improvement of oleuropein extractability by optimising steam blanching process as pre-treatment of olive leaf extraction via response surface methodology. Food Chemistry 133: 344-351. https://doi.org/10.1016/j.foodchem.2012.01.038

Tan, H.W., Tuck, K.L., Stupans, I. and Hayball, P.J., 2003. Simultaneous determination of oleuropein and hydroxytyrosol in rat plasma using liquid chromatography with fluorescence detection. Journal of Chromatography B 785: 187-191. https:// doi.org/10.1016/S1570-0232(02)00855-3

Tripoli, E., Giammanco, M., Tabacchi, G., Di Majo, D., Giammanco, S. and La Guardia, M., 2005. The phenolic compounds of olive oil: structure, biological activity and beneficial effects on human health. Nutrition Research Reviews 18: 98-112. https://doi.org/10.1079/NRR200495

Uzel, R.A., 2018. Effect of extraction method and extraction solvent on recovery of phenolic compounds from olive leaves in Kemalpaşa-İzmir (Turkey): oleuropein recovery as a case example. Separation Science and Technology 53: 1-9. https://doi.org/ 10.1080/01496395.2018.1442861

Vilkhu, K., Mawson, R., Simons, L. and Bates, D., 2008. Applications and opportunities for ultrasound assisted extraction in the food industry-a review. Innovative Food Science and Emerging Technologies 9: 161-169. https://doi.org/10.1016/j. ifset.2007.04.014
Visioli, F., Poli, A. and Gall, C., 2002. Antioxidant and other biological activities of phenols from olives and olive oil. Medical Research Review 22: 65-75. https://doi.org/10.1002/med.1028

Vissers, M.N., Zock, P.L., Roodenburg, A.J.C., Leenee, R. and Katan, M.B., 2002. Olive oil phenols are absorbed in humans. The Journal of Nutrition 132: 409-417. https://doi.org/10.1093/ jn/132.3.409

Vural, N., Cavuldak, O.A., Kenar, A. and Akay, M.A., 2020. Green alcoholic solvent and UAE extraction of oleuropein from the Olea europaea L. leaves: experimental design, optimization, and comparison with Pharmacopoeia method. Separation Science and Technology 55: 1813-1828. https://doi.org/10.1080/014963 95.2019.1606014

Xie, P.J., Huang, L.X., Zhang, C.H., You, F., Wang, C.Z. and Zhou, H., 2015. Reduced pressure extraction of oleuropein from olive leaves (Olea europaea L.) with ultrasound assistance. Food and Bioproducts Processing 93: 29-38. https://doi.org/10.1016/j. fbp.2013.10.004

Xynos, N., Papaefstathiou, G., Psychis, M., Argyropoulou, S., Aligiannis, N. and Skaltsounis, A.L., 2012. Development of a green extraction procedure with super/subcritical fluids to produce extracts enriched in oleuropein from olive leaves. Journal of Supercritical Fluids 67: 89-93. https://doi.org/10.1016/j. supflu.2012.03.014

Yang, Y., Zhang, F., 2008. Ultrasound-assisted extraction of rutin and quercetin from Euonymus alatus (Thunb.) Sieb. Ultrasonics Sonochemistry 15: 308-313. https://doi.org/10.1016/j. ultsonch.2007.05.001

Yasemi, M., 2020. Optimization of oleuropein extraction from olive leaves using artificial neural network. Journal of Applied Chemical Research 14: 23-35. Available at: http://jacr.kiau.ac.ir/ article_673084_3088249e10734c8fa0ee7792da794747.pdf.

Yasemi, M., Heydarinasab, A., Rahimi, M. and Ardjmand, M., 2017. Microchannels effective method for the extraction of oleuropein compared with conventional methods. Journal of Chemistry 2017: 6594156. https://doi.org/10.1155/2017/6594156

Zhang, Q.W., Lin, L.G. and Ye, W.C., 2018. Techniques for extraction and isolation of natural products: a comprehensive review. Chinese Medicine 13: 1-26. https://doi.org/10.1186/ s13020-018-0177-x

Zoidou, E., Magiatis, P., Melliou, E., Constantinou, M., Harourounian, S. and Skaltsounis, A.L., 2014. Oleuropein as a bioactive constituent added in milk and yogurt. Food Chemistry 158: 319-324. https://doi.org/10.1016/j.foodchem.2014.02.137 